\title{
Demand Structure and the Consumption of Garri in Owerri North Local Government Area of Imo State, Nigeria
}

\author{
Chima I. Ezeh ${ }^{1, *}$, Chidozie O. Anyiro ${ }^{1}$, Ngozi Q. Obioma ${ }^{2}$, Obioha. C. Maduagwu ${ }^{1}$ \\ ${ }^{1}$ Department of Agricultural Economics and Extension Abia State University, Umuahia Campus, Umuahia Abia State, Niger ia \\ ${ }^{2}$ Department of Agricultural Extension Abia State ADP Headquarters Ossah, Umuahia Abia State, Nigeria
}

\begin{abstract}
The study analysed empirically the demand structure and the consumption of garri in Owerri North L.G.A. of Imo state, Nigeria and sought to determine the factors that influence the monthly budget share for garri at low, medium and high income levels, estimate own price, cross price and income elasticit ies of demand for garri and as well to determine the factors that influence preference for a particular garri brand. In order to achieve this mandate, Simple random and judgmental samp ling techniques were used to select communities, their markets and 80 respondents. A set of pretested and structured questionnaire was used in data collection. Multiple regression model, demand elasticity indicators and logit regression model were the tools of analysis adopted for th is study. The result of the mult iple regression analysis with semi log, as lead equation showed that the critical and significant determinants of monthly budget share for garri among low income consumers were household size, price of garri and monthly incomes at given levels. The comb ined effect of all the variables explained $77.8 \%$ of the variation in the monthly budget share for garri at $1.0 \%$ risk level. The result of the multiple regression analysis with exponential functional form as the lead equation showed the critical and significant determinants of monthly budget share for garri among the middle income consumers were number of years spent in school, household size and monthly inco mes. All the variables exp lained $81.8 \%$ of the variation in the monthly budget share for garri among the middle income consumers. The result also showed that the own price elasticity of demand for garri was 0.03 while cross elasticity of demand forgarriand fufu, samovita, yam floor and cas sava floor were $2.3,1.8,1.4$ and 1.4 respectively. The inco me elasticity of demand for garri was 0.3 . The logistic regression estimation showed that the determinants for preference of garri include price, colour perception, age and education which were statistically significant at $1.0 \%$ risk level. It was recommended that there is the need for all consumers in different income strata (low, medium and high) to patronize garri of all colours in order to act as impetus to farmers to produce more and increase their inco me.
\end{abstract}

Keywords Demand, Structure, Consumption, Income, Elasticities

\section{Introduction}

Cassava (Manihot spp) is an important crop widely cultivated in Sub-Saharan Africa. Although, the crop is grown virtually in all parts of the sub-continent, production is specific in the humid tropics[1]. Cassava plays a major role in efforts to alleviate Nigeria's food crisis because of its efficient production of food energy, all year round availability, tolerance to extreme stress conditions and suitability to various farming and food systems[2]. Cassava is capable of providing food energy much more than maize, sorghum and rice[3]. Garri, a product from cassava, constitutes more than $70 \%$ of total cassava consumption in

* Corresponding author:

chimaezeh@yahoo.com (Chima I.Ezeh)

Published online at http://journal.sapub.org/ijaf

Copyright (C) 2012 Scientific \& Academic Publishing. All Rights Reserved
Nigeria[4]. Thus, garri is one of the staple food items consumed in Nigeria. It therefore implies that garri is eaten by every family irrespective of their socio-economic status and religious background. Thus, garri commands much interest and hence gets a considerable preference on the hous ehold daily budget. This means that there will be across the board high demand for the product.

Evidence had shown that food production in Nigeria has not kept pace with the increasing population. The annual growth rate of the food sub-sector is 2.0 percent while the annual population growth rate is 3.3 percent[5]. This presupposes that a wide gap existed between food supply and the demand for food by the nation's populace. The seasonality of agricultural products causes price instability. Evidence has shown that periods of surpluses are usually supplanted by periods of scarcity. This vagary in the price variable cause unpredictable fluctuations in the demand and supply factors. In addition, there are other factors that 
influence the purchase decision of consumers such as organoleptic features as colour, taste, aroma, texture, physio-chemical and hydrogen cyanide $(\mathrm{HCN})$ residues.

Ezedinma and Oti, stated that the traditional methods of cassava processing into garri are often contaminated with undesirable extraneous matters that make them unhygienic thereby affecting demand and consumption[6]. There is therefore the dire need to know the demand structure for garri at a micro setting such as Owerri North Local Government area of Imo State, so as to build a bridge between, processing, availability, affordability and consumption. The significance of this study will to a large extent contribute to good farm policy formulation and market strategies that will enhance the growth of the food sector. This research is anchored on the following specific objectives;

i. to determine the factors that influence the monthly budget share for garri at low, medium and high income levels in the study area.

ii. to estimate own price, cross price and income elasticities of demand for garri in the study area.

iii. to determine factors that influence preference for a particular garri brand in the study area.

The following hypothesis were tested:

$\mathrm{Ho}_{1}$ Monthly budget share for garri among low, medium and high income groups is positively related to literacy level, age, household size, price and monthly income.

$\mathrm{Ho}_{2}$ Own price, cross price and income elsticities of demand for garri is zero.

$\mathrm{Ho}_{3}$ Preference to a particular garri type is positively influenced by price, colour, taste, texture, age of consumer and educational level of consumers.

\section{Research Methodology}

The study was carried out in Owerri North Local Government Area of Imo State, Nigeria. The choice was purposive. This was informed by the predominance of civil servants and existence of a large daily market in the area. The L.G.A was created in 1996 and had a population of 289,721[5]. It lies between latitudes $4^{\circ} 5^{\prime}$ and $6^{\circ} 5^{\prime}$ North of Equator and Longitudes $6^{\circ} 30^{\prime}$ and $8^{\circ} 9^{\prime}$ east of green wich meridian. Owerri North LGA is bounded in the North by Mbaitoli and Ikeduru LGAs and west by Owerri West and Owerri Municipal LGAs of Imo State, Nigeria[7].

Random sampling technique was used to select eight markets fro meight co mmun ities. The eight commun ities and their markets selected were Emekuku, Awaka, Orji, Naze, Uratta Egbu and Obube. Judg mental sa mpling technique was used to select garri buyers from various daily markets in the area. Data was obtained with the use of structured and pretested questionnaire administered on the respondents. Objective one was achieved using multiple regression analysis while objective two was analyzed with demand elasticity indicators. Objective three was realized with Logit regression model.
The implicit model of the ordinary least square (OLS) multiple regression is stated thus;

Where

$$
\mathrm{Q}=\mathrm{F}\left(\mathrm{X}_{1}, \mathrm{X}_{2}, \mathrm{X}_{3}, \mathrm{X}_{4}, \mathrm{X}_{5}, \text { ei }\right)
$$

$\mathrm{Q}=$ Monthly Budget share of garri $(\#)$

$\mathrm{X}_{1}=$ Years spent in school

$\mathrm{X}_{2}=$ Age of the consumer (years)

$\mathrm{X}_{3}=$ Household size

$\mathrm{X}_{4}=$ price of garri ()

$\mathrm{X}_{5}=$ Income per month (

The demand function was regressed using four different functional forms namely linear, exponential, double log and semi-log and the one with the best fit in terms of a priori expectation, statistical and econometric criteria was used as the lead equation.

The own price elasticity is stated thus:

$$
\text { Exy }=\frac{\partial \mathrm{Qx}}{\partial \mathrm{py}} \quad \frac{\mathrm{Py}}{\mathrm{Qx}}
$$

Where: $\mathrm{ep}=$ price e las ticity

$$
\begin{aligned}
& \frac{\partial \mathrm{Q}}{\partial \mathrm{y}}=\text { slope of the linear demand curve } \\
& \mathrm{Q}=\text { quantity demanded } \\
& \mathrm{P}=\text { price of commodity. } \\
& \text { The cross price elasticity is stated thus: }
\end{aligned}
$$

$$
\text { Exy }=\frac{\partial \mathrm{Qx}}{\partial \mathrm{py}} \quad \frac{\mathrm{Py}}{\mathrm{Qx}}
$$

Where:

Exy $=$ cross elasticity of commodity $\mathrm{X}$ with regard to commodity $\mathrm{Y}$

$\mathrm{Qx}=$ Quantity demanded of co mmod ity $\mathrm{X}$

$\mathrm{Py}=$ price of commodity $\mathrm{Y}$

The income elasticity is specified as

$$
\frac{\partial \mathrm{Q}}{\partial \mathrm{y}} \cdot \frac{\mathrm{y}}{\mathrm{Q}}
$$

Where

$\mathrm{Q}=$ quantity of the goods demanded

$\mathrm{Y}=$ Consumers income

The Logit model is generally imp lic itly specified thus

$$
\mathrm{Zi}=\text { bo }+\mathrm{biXi}_{1} \mathrm{i}+\mathrm{b}_{2} \mathrm{X}_{2} \mathrm{i}+\text {----- }+ \text { bp Xij }
$$

Where

$\mathrm{Zi}=$ unobserved continuous variable for the ith case.

$\mathrm{Xij}=$ the $\mathrm{jth}$ coefficient (independent variables)

$\mathrm{P}=$ number of pred ictors.

This model is explicitly explained as:

$\mathrm{Zi}=\mathrm{bo}+\mathrm{b}_{1} \mathrm{X}_{1}+\mathrm{b}_{2} \mathrm{X}_{2}+\mathrm{b}_{3} \mathrm{X}_{3}+\mathrm{b}_{4} \mathrm{X}_{4}+\mathrm{b}_{5} \mathrm{X}_{5}+\mathrm{b}_{6} \mathrm{X}_{6}$

$\mathrm{Zi}=$ preference to the garri type

$\mathrm{X}_{1}=$ price of garri ( $)$

$\mathrm{X}_{2}=$ Colour of garri (Dummy: white I; Yellow $=0$ )

$\mathrm{X}_{3}=$ Taste (Dummy: sweet taste $=\mathrm{I}$; sour $=0$ ) 
$\mathrm{X}_{4}=$ Textu re (Dummy: fine $=\mathrm{J}$; Gritty $=0$ )

$\mathrm{X}_{5}=$ Age (years)

$X_{6}=$ Nu mber of years spent in school.

\section{Result and Discussion}

The factors that influenced the monthly budget share of garri by the different income groups are shown in Tables I and 2. The income groups under study were low, medium and high income groups. The bench mark for the stratification was according to Okorji and Ezeh that categorized monthly income levels of N50, 000.00 as low income, N50, $001-\mathrm{N} 100,000.00$ as medium income and above N100, 000.00 was high income group[8;9]. In the study area, only the low and medium income groups were identified and presented based on the above bench mark.

The result in Table 1 shows the factors that influenced the budget share for garri among the low income households in Owerri North LGA of Imo state Nigeria. It shows that all the estimated functions were significant. $(\mathrm{P}<0.01)$. This implies that the functional forms were adequate in explaining the variations in the dependent variables. However, among the four functional forms (Linear Exponential, Double and Semi-Log) used for estimating the monthly budget share of garri among the low inco me consumers in the study area, the semi-log functional form was chosen as the lead equation based on econometric and statistical reasons such as the number of regression coefficients that are significant, the value of $\mathrm{R}^{2}(0.778)$ and the significant level of F-ratio $(\mathrm{P}<$ 0.01 ).

Specifically, household size is directly related to the monthly budget share of the low income consumers. The coeffic ient is 2.526, while the standard error is 0.952 and the variable is statistically significant at $1.0 \%$ probability level. Expectedly, consumers with large household size are likely to spend greater proportion of the monthly budget on garrithe basic staple and other basic household requirement. Although, Christianity restricts the number of wives in the household, many low income household sizes are relatively large. This situation has posed serious problems in recent times, due to the present economic crises and is responsible for the high rate of malnutrition, illiteracy and unemploy ment, especially in the rural economy [8; 9].

The price of garri made marginal contribution to the equation. The coefficient ( 0.976$)$ is positive and the standard error is 0.149 . The variable is statistically significant at 1.0 percent risk level. The sign of the variable is in conformity with a priori expectation in that a higher price would cause the consumer to allocate a larger proportion of the monthly budget to garri purchase. This is because higher prices cause the value of real incomes to fall, thus causing a large share of the budget to be devoted to the purchase of the commodity. But when prices fall, the value of real income rises, greater quantity of the good in question can be bought with reduced amount of the budget[10].

The coefficient of the income per month of the low income consumers (8.612) made positive contributions to the equation and the standard error is 3.768 . The variable is statistically significant at $5.0 \%$ alpha - level. The sign is in accordance with a priori reasoning. Expectedly, the positive sign imp lies that the monthly budget share of the low inco me consumers to garri increases as the monthly income increases.

Table 1. Estimates Of Factors That Affects The Monthly Budget Share For Garri Of Low Income Consumers In Owerri North Local Government Area Of Imo State, Nigeria

\begin{tabular}{|c|c|c|c|c|}
\hline & & Function & Forms & \\
\hline Variables & Linear & Semi-log ${ }^{+}$ & Exponential & Double log \\
\hline \multirow[t]{2}{*}{ Constant } & -80.203 & $6.070 * * *$ & $5.869 * * *$ & 1.600 \\
\hline & (229.309) & $(1.044)$ & $(0.210)$ & $(1.183)$ \\
\hline \multicolumn{5}{|l|}{ Number of years } \\
\hline \multirow[t]{2}{*}{ Spent in school (X1) } & 1.534 & 0.010 & 0.010 & 0.156 \\
\hline & $(10.286)$ & $(0.009)$ & $(0.009)$ & $(0.250)$ \\
\hline \multirow[t]{2}{*}{ Age (X2) } & 0.249 & 0.288 & 0.000 & -0.041 \\
\hline & (3.896) & $(0.361)$ & $(0.004)$ & $(0.154)$ \\
\hline \multirow[t]{2}{*}{ Household size (X3) } & 14.896 & $2.526^{* * *}$ & $0.076^{* * *} *$ & 0.080 \\
\hline & $(25.410)$ & $(0.952)$ & $(0.024)$ & $(0.085)$ \\
\hline \multirow[t]{2}{*}{ Price of garri (X4) } & 3.593 & $0.976^{* * *}$ & $0.003^{* * *}$ & $0.858 * * *$ \\
\hline & $(0.263)$ & $(0.149)$ & $(0.000)$ & $(0.102)$ \\
\hline \multirow[t]{2}{*}{ Monthly income (X5) } & 0.003 & $8.612 * * *$ & $3.612 * *$ & 0.025 \\
\hline & $(0.004)$ & $(3.768)$ & $(1.768)$ & $(0.097)$ \\
\hline R2 & 0.784 & 0.778 & 0.708 & 0.758 \\
\hline R Squared Adjusted & 0.765 & 0.693 & 0.674 & 0.724 \\
\hline F-ratio & $42.721 * * *$ & $25.654 * * *$ & $20.877 * * *$ & $21.936^{* * *}$ \\
\hline
\end{tabular}

Source: computations from field survey data, 2010 .

+ Lead equation

***, *: indicate variables are statistically significant at $1.0 \%$ and $5 \%$ risk levels respectively.

Figures in parentheses are standard errors. 
Table 2. Est imates Of Factors That Affect The Monthly Budget Share For Garri Of Middle Income Consumers In Owerri North L.G.A, Imo State, Nigeria

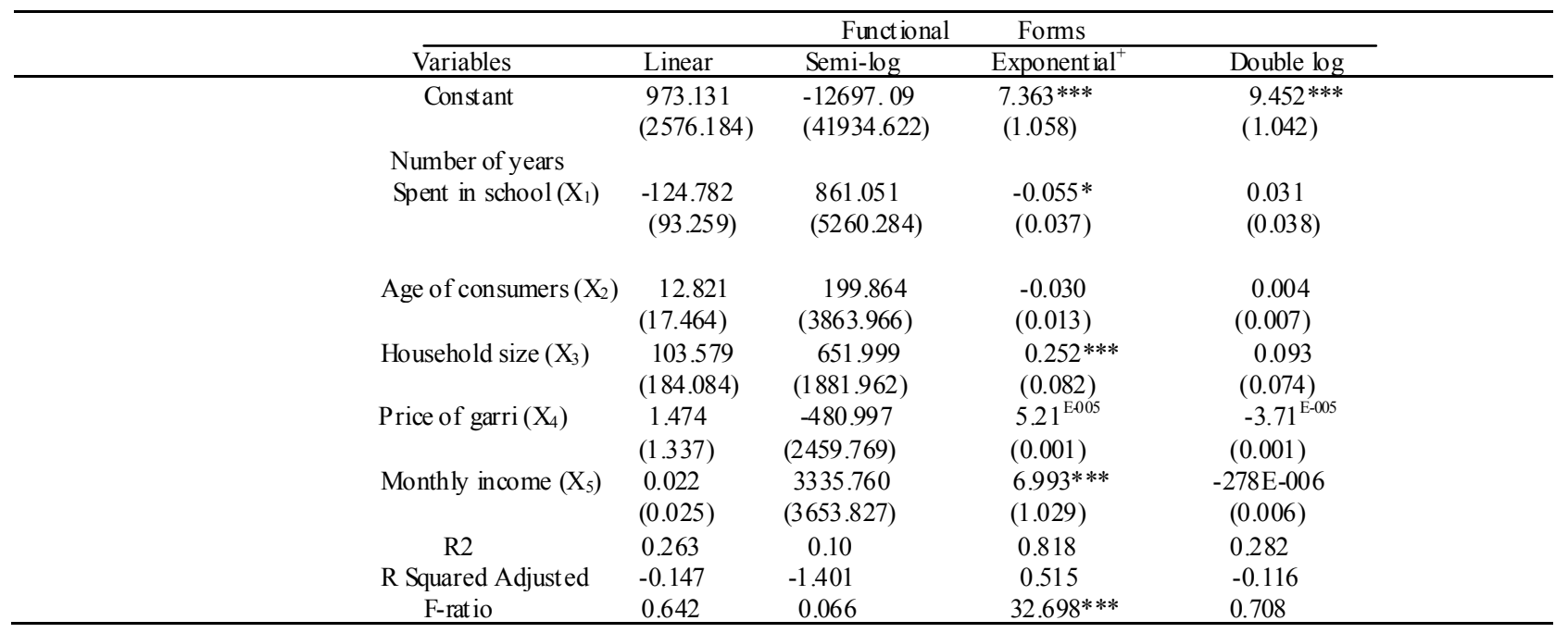

Source: computations from field survey data, 2010 .

${ }^{+}=$Lead equation

***, *: indicate variables are statistically significant at $1.0 \%$ and $10.0 \%$ risk levels respectively

Table 3. Estimate of Own Price, Cross Price and Income Elasticities of Demand for garri in Owerri North L.G.A, Imo State Nigeria

\begin{tabular}{ccc}
\hline Category of Demand & Commodity & Elasticity Coefficients \\
Elasticity & & 0.03 \\
Own Price & Garri & 2.3 \\
Cross Price & Garri and Fufu & 1.8 \\
Cross Price & Garri and Semovita & 1.4 \\
Cross Price & Garri Yam flour & 1.4 \\
Cross Price & Garri and Cassava flour & 0.3 \\
Income & Garri & \\
\hline
\end{tabular}

Source: Computation from field survey data, 2010

Table 4. Estimate OfThe Logistic Regression Analysis On Factors That Influence The Preference Of Garri In Owerri North LGA, Imo State, Nigeria

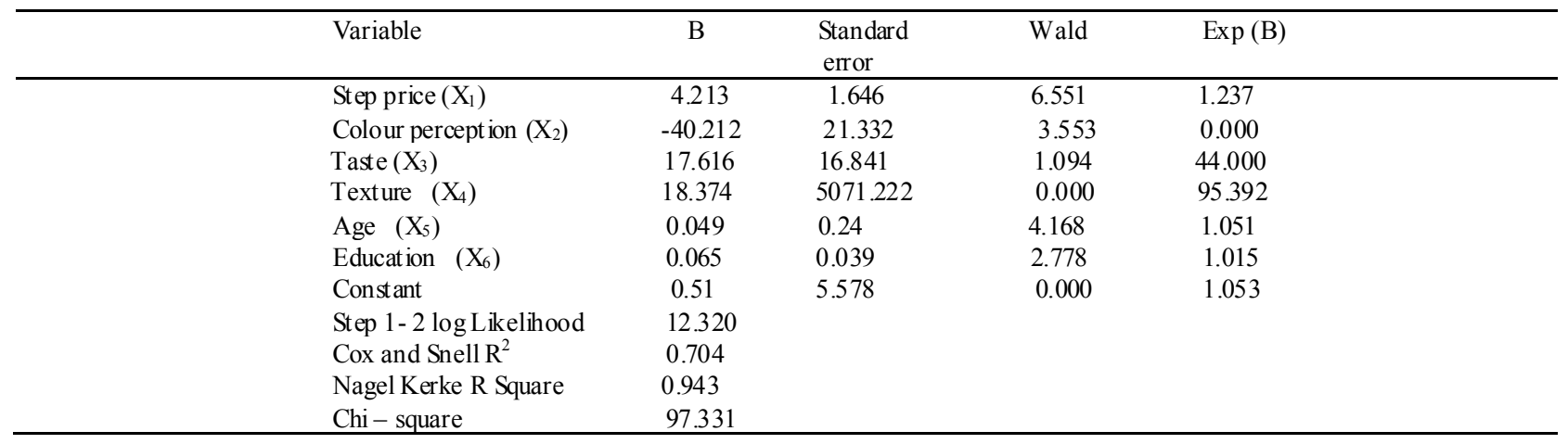

Source: computations from field survey data, 2010

The result of the multiple regression analysis on the factors that influence the monthly budget share for garri of medium income consumers in Owerri North LGA of Imo state, Nigeria is shown in Table 2. A mong the four functional forms (Linear, Exponential, Double and Semi-Log) used for estimating the monthly budget share for garri among the middle income consumers, the exponential functional form was chosen as the lead equation based on econometric and statistical reasons, such as the number of regression coefficients that are significant, the value of $R^{2}(0.818)$ and the significant level of the F-ratio $(\mathrm{P}<0.01)$.

The coefficient of the number of years spent in school $(-0.55)$ is marginal and negative while the standard error is
0.037. The variable is statistically significant at $90.0 \%$ confidence level. The sign of the coefficient is in conformity with a priori expectation that the monthly budget share for garri of medium income consumers would reduce as the number of years spent in school increases. Consumers with high level of education are expected to evaluate food product by their prices and specific nutritive quality rather than by popularity before allocating a given share of the monthly budget to the commodity [11;12].

The coefficient of hous ehold size is 0.252 and the standard error is 0.082 . The variable is statistically significant at $99.0 \%$ confidence level. Accordingly, it is expected that middle income consumers with large household size would likely 
spend a greater proportion of their monthly budget share on garri, which is the basic staple food available and affordable all year round.

The coefficient of income per month (6.993) is positive with a standard error of 1.029 . The variable is statistically significant at $1.0 \%$ probability level. The sign of the variable is in consonance with a priori expectation. It implies that as the monthly incomes of the middle income consumers increases, the budget share allocated to garri purchase would also increase.

The values of the own price, cross price and income elasticities of demand for garri is shown in Table 3. The result shows that the own price elasticity of garri was 0.03 . This shows that a percentage change in the price of garri would result in a less than proportionate change in the quantity demanded of it, hence being perfectly inelastic. This result compared favourably with Effiong[13] that obtained -0.83 as own price elasticity in pork demand in Cross River State of Nigeria. This reinforces the readily availability of garri with very minimal variation in the price level.

The values of cross price elasticities of demand for garri with fufu, samovita, yam flour and cassava flour were 2.8, $1.8,1.4$ and 1.4 respectively. This implies that a one percent increase in price of garri, will increase the consumption of fufu by 2.3 , samovita by 1.8 , yam flour by 1.4 and cassava flour by 1.4 in the study area. This indicates a strong degree of competitiveness and substitutability of these goods with garri.

The income elasticity of demand for garri is shown in Table 3. The Table shows that the income elasticity of demand for garri was 0.3 . This implies that as consumers' income increase, a smaller or declining portion of their income will be spent on the product. This result is consistent with Effiong result in the consumption of pork[13]. Engel's law in terms of elasticity agrees that food is income elasticity. However, a change in consumer's money inco me will have a significant influence on consumption of the product either increasing or decreasing consumption.

The results of the Logistic regression on the factors that influence the preference of garri by consumers in Owerri North LGA of Imo state, Nigeria is shown in table 4. The logistic regression estimation for the variables showed that the effect coefficient $\operatorname{Exp}$ (B) for price, colour perception, age and education were statistically significant at $1.0 \%$ risk level as shown by the Wald test.

In terms of price, the result revealed that higher prices induced medium income consumers to have the preference and the willingness to consume white garri. Similarly, the perception of colour had a positive relationship with preference. This shows that there exists dominant preference for white garri in the study area, contrary to the widely held scientific opinion that yellow garri contains more nutrients especially vitamin A supplied by the colour additive than the white garri. This result is inconsistent with the Umberger et al[14] assertion that quality and health peculiarities are important factors for preference and willingness to consume food.
With odds ratio of more than one, both the effect coefficient of age and education had positive significant influence on preference for white garri. By implication, increasing age and education impacted positively on preference and willingness to consume white garri in the study area. Older consumers with higher level of education are expected to evaluate food products by their price and specific quality rather than by popularity[11]. The Cox-Snell and Nagel Kerke $\mathrm{R}^{2}$ values are attempting to provide a logistic analogy like the coefficient of multiple determination $\left(\mathrm{R}^{2}\right)$ in OLS regression. At $70.4 \%$ and $94.3 \%$ for Cox-Snell and Nagel Kerke respectively, the regression line fit the data appreciably high and imply the extent of explanation of the variation in the dependent variable. The result consolidates the findings of Nwachukwu et al, who had similar outcome[15].

\subsection{Conclusions and Recommendations}

Consumers have been recurrently the unit of analys is in all economic activities. Each individual want to maximize utilities but due to budget constraint must resorts to alternatives. Alternatives in terms of whether it will satisfy their need or not must be evaluated. From the analys is of the demand structure and the consumption of garri, this study reveals that the major determinants of the monthly budget share for garri among low income consumers in Owerri North LGA in Imo state, Nigeria with Semi-log as lead equation were household size, price of garri and monthly incomes while the determinants of the monthly budget share for garri among middle income consumers with exponential functional form as the lead equation were number of year spent in school, household size, and monthly income.

The values of own price elasticity of demand for garri was 0.03 while cross price elasticities between garri and fufu, samovita, yam flour and cassava flour were $2.3,1.8,1.4$ and 1.4 respectively. The income elasticity of demand for garri was 0.3 .

The logistic regression estimation showed that price, colour perception, age and education were the critical determinants of preference for white garri and were statistically significant at $1.0 \%$ risk level.

The study recommends a policy such as sustained increase in the salary of the working class consumers by the government. Higher incomes would increase the propensity for increased purchases hence increased income to the farmers.

All consumers in different income strata (low, middle and high) are encouraged to consume garri of any colour as this would be added impetus required by farmers to produce more and increase their incomes in so doing.

\section{REFERENCES}


[1] Okereke, K.A; E. Dosso and R.A. Salau (2001), Cassava based cropping system in Africa. African Journal of Root and Tuber Crops. 4 (2): 1-9.

[2] Awah, E.T and A. Tumanteh (2001) Cassava Based Cropping System And Use Of Inputs In Different Ecological Zones Of Central Africa, African Journal Of Root And Tuber Crops 4 (2); 71-81

[3] Achinihu, S.C and C.I Onuamanam (2001) Ramification of Five improved Cassava Cultivars in Nigeria and Physico-chemical and Sensory Properties of Garri Yield. African Journal of Root and Tuber Crops 4 (2); 110-118.

[4] Dorosh, P. (1989) Economics of Cassava in Africa. Summary of proceeding of a Workshop on Trends and prospects of Cassava in the third World.

[5] National Bureau of Statistics (NBS) (2002) Digest of Statistics. Published by FOS printing press Ikoyi Lagos.

[6] Ezedinma, C.I. and N.N. Oti (2001) Scio-economic issues in the development of cassava processing Technology in Nigeria. Journal of Sustainable Agriculture and the Environment. 3 (1); 21-33.

[7] Imo State Government (IMSG) (1997), Agricultural Credit Edict, Supplement to Imo State. Nigeria Gazette 3 (2) Edict No. I 1997.

[8] Okorji, E.C. (1999) Dimensions of Rural Poverty and Food Self Sufficiency in Nigeria. Poverty Alleviation and Food Security in Nigeria. Y.L Fabiyi and Idowu E.O. NAAE Ibadan p.53.
[9] Ezeh, C.I. (2007), Poverty Profiles and Determinants of Expenditures of Rural Women Households in Nigeria. The Nigerian Journal of Development Studies 6 (1) 187-204.

[10] Oji, K.O. (2002), Basic Principles of Economics. Prize publisher, Nsukka, Nigeria

[11] Henseliet, M.S. Kubitzki and R. Teuber (2007), Determinants of Consumer Preferences for Regional Food. Papter presented at the $105^{\text {th }}$ EAAE Seminar in Bolongs, Italy 8-10 March.

[12] Maduagwu, O.C (2008), Demand Structure and Consumption of Garri in Owerri North LGA Imo State, Nigeria. B A gric Thesis; Department of Agricultural Economics and Extension Abia State University Uturu.

[13] Effiong, E.O. (2004), Pork Consumer Behaviour in Cross River State, Nigeria; An Emperical Evidence. Journal of Agriculture and Food Science. 2(1); 43-47.

[14] Umberger, N.J; D.M Feiz, Calkins and B.M. Sitz (2003). Country of Origin Labeling of Beef Products and Consumers' Perception. Journal of Food Distribution research pp. 103-116.

[15] Nwachukwu I.N; M.M Agwu and C.I. Ezeh (2008), Comparative Study of Consumer Purchase Attitude of Local Foreign Rice in Abia State. Proceeding of $42^{\text {nd }}$ Annual Conference of Agricultural Society of Nigeria held at Ebonyi State University Abakaliki. Oct. 19-23 ${ }^{\text {rd }}$. 764-767. 